\title{
EVIDENCE FOR ENDOCRINE DISRUPTING EFFECTS OF LEAD ON TELEOST CIRRHINUS MRIGALA
}

KEY WORDS: Cirrhinus

Mrigala, Lead, Endocrine, Teleost

\section{R. Chavan*}

Department of Zoology, Shri Vijaysinha Yadav College, Peth Vadgaon, Dist. Kolhapur, Pin 416112 (Maharashtra), India. *Corresponding Author

Lead is one of the elements that can be described as purely toxic. Lead displaces biologically important metals interfering with a variety of body's chemical reactions. A variety of environmental contaminants including heavy metals interfere the endocrine axis of fish. Lead is reported with endocrine disruptive potential. Lead affects the hypothalamus pituitary gonadal axis at multiple sites. In the present work an effort is made to explore qualitative changes in the pituitary gland cell types of Cirrhinus mrigala after an acute and chronic exposure to lead. The study revealed the toxic effects of lead on endocrine functions of a teleost which further affects the fecundity of fish. The present study provides a manifold confirmation on the endocrine disrupting effects of lead in fish.

\section{INTRODUCTION}

Lead is oldest and versatile common metal. It has a long environmental persistence and never loses its toxic potential if ingested. The toxic effects of lead have been reported for over 2000 years in both humans and animals [1-2]. Recent reports indicated that lead can cause neurological, gastrointestinal, reproductive, circulatory, immunological, histopathological and histochemical changes in the animals [3-5]. Lead displaces biologically important metals such as calcium, zinc and magnesium interfering with a variety of body's chemical reactions. Low levels of lead pollution could cause some adverse effects on fish health and reproduction [6-7]. The endocrine master gland pituitary is a complex neuroepithelial structure. The teleostean pituitary varies in the organization, arrangement and orientation of its different components from species to species. The anterior, intermediate, and posterior lobes of the pituitary gland act as separate entities and distinct cell populations, secretory products and regulatory mechanisms characterize each. The morphological, histological and histochemical studies on the pituitary gland of Cirrhina mrigala Lal et al. [8]. gave a view to gain insight into seasonal changes in cellular composition of pituitary gland. Studies on fish pituitary glands proved that many physiological functions like growth, reproduction, reproduction related behavior, instinct for nitrification, regulation of body electrolyte balance and gonad development are controlled by hormones that are released from the pituitary gland, in the same way that it functions in mammals [9-10]. The pituitary gland contains highly differentiated and committed cells which synthesize unique hormone products. Different cell types of pituitary progress after initial patterning only after the induction of specific transcription factors [11-12].

The gonadotropes vary depending on the moment of the reproductive cycle, age and sex of the animal. Seasonal changes in the gonadotropes during the annual reproductive cycle have been reported in fish [13-15]. A variety of environmental contaminants including heavy metals interfere the endocrine axis in fish [16-17]. Heavy metals such as lead, cadmium, arsenic, nickel, zinc and mercury are also reported to have an endocrine disruptive potential. $\mathrm{Pb}$ contamination may alter endocrine regulated processes such as longevity, development, sexual receptivity, fertility and locomotion [18]. Gonads of teleosts are affected by lead pollution which thereby affect reproductive behaviour [19]. Secretary activity of pituitary has been shown to be affected by metals [20] and is proved to be a soft target for cadmium. Female rainbow trout exposed to lead reduced the mean number of basophil responsible for GTH production [21]. Pb affects the hypothalamus-pituitarygonadal axis at multiple action sites Ronis et al., [22] and causes reproductive impairment [23].Various heavy metals are often present in the same polluted environment at the same time, studies of their interactive effects on gonadal activity would be more meaningful. Considering all these evidences, the present work was undertaken to investigate the changes in pituitary gland of C. mrigala after an acute and chronic exposure to lead acetate.

\section{MATERIALS AND METHOD:}

C. mrigala (70-72g weitht and $19-20 \mathrm{~cm}$ length) irrespective of sex were collected from reservoir at Kalambe village near Kolhapur, Maharashtra, India. Fishes were acclimatized for 15 days to laboratory conditions. The laboratory water was analyzed for different physico-chemical parameters (APHA, 2010) and for lead. LC50 for lead acetate was statistically determined [24].Well acclimatized fishes showing no signs of stress were selected and divided into three groups of ten each for exposure to toxicant. The first group served as a control and other two groups were exposed to sublethal concentrations of lead acetate. A dose of $28.2 \mathrm{ppm}\left(1 / 10^{\text {th }}\right.$ of LC50) and $14.1 \mathrm{ppm}\left(1 / 20^{\text {th }}\right.$ of LC50) of lead acetate was administered to experimental group daily for 30 days. The experiment was carried out in replicate both for acute (96 hrs.) and chronic (30 days). Immediately after completion of exposure period the fish of both the sexes were decapited to locate pituitary gland. The pituitary gland was fixed in Bouin's fluid for 48 hours with a change after 24 hours. Fixed tissues were processed for sectioning. The sections of pituitary gland were stained with Azan Heidenhain method for identification of the pituitary cell types, because the Azan stain intensifies the differences between acidophils, basophils and chromophobes. Azan' Stain, Mallory Heidenhain's [25] staining of Pituitary gland was followed.

\section{Immunohistochemisty for pituitary gland:}

Preparation of working solution Phosphate Buffered Saline (PBS):

To $800 \mathrm{ml}$ of double distilled water in a flask $8 \mathrm{gm} \mathrm{NaCl}, 0.2 \mathrm{~g}$ $\mathrm{KCl}, 1.44 \mathrm{~g}$ of $\mathrm{Na}_{2} \mathrm{HPO}_{4}$ and $0.25 \mathrm{~g}$ of $\mathrm{KH}_{2} \mathrm{PO}_{4}$ were added and dissolved. The $\mathrm{pH}$ of solution was adjusted to 7.4 with $1 \mathrm{M} \mathrm{HCl}$. The solution was poured in a volumetric flask and final volume was made to lliter. $440.05 \%$ Diaminobenzedine tetrahydrochloride (DAB) in $0.015 \% \mathrm{H}_{2} \mathrm{O}_{2}: 50 \mathrm{mg} \mathrm{DAB}$ (Diaminobenzedine tetrahydrochloride) in $100 \mathrm{ml}$ PBS added with $250 \mu 16 \% \mathrm{H}_{2} \mathrm{O}_{2}$. Source and working dilutions of antisera Anti-chorionic Gonadotropin (alpha + beta subunits) (HCG) antibody produced in rabbit (Sigma Aldrich, product number C8534) was used as primary antibody.The primary antiserum was diluted with PBS at dilution of 1:100.

Anti-Rabbit IgG -Peroxidase produced in goat (SigmaAldrich, product number Ao545) was used as secondary antibody. The secondary antibody was diluted with PBS at a dilution of 1:400. For immunohistochemical analysis, pituitary tissue sections were immunostained by using anti-human chorionic gonadotropin (a and B chain) developed in rabbit as a primary antisera and anti-rabbit IgG peroxidase 
produced in goat as secondary antisera. To confirm the specificity of the immunoreactive procedures, adjacent sections were validated according to the steps, but the primary antiserum was replaced with PBS or normal secondary antibody (instead of primary antiserum). Following immunostaining, the sections were examined and documented using image.

\section{RESULTS AND DISCUSSION}

A-1) Control Pituitary Gland: The control pituitary gland showed a spherical appearance. Histologically the gland showed two distinguished components adenohypophysis and neurohypophysis. The typical three regions of adenohypophysis RPD, PPD and PI were recognizable. The RPD showed smaller but distinct acidophils. The PPD was populated by small gonadotropes. Thyrotropes and somatotropes were also observed. The gonadotropes were without secretary granules (Fig. $1(1,2,3)$ ).

A-2) LC0:The examination of pituitary gland after exposure to LC0 concentration (250ppm) of lead acetate for $96 \mathrm{~h}$, showed similar organization of the cells like control. However, the population of all types of cells appeared to be decreased. The abundance of gonadotropes was reduced. Penetration of thick nerve fibres was noticed in PI. (Fig. $1(4,5,6)$ ).

A-3) LC50: The examination of pituitary gland after exposure to LC50 concentration (282ppm) of lead acetate for $96 \mathrm{~h}$ showed altered organization. Acidophils in RPD and PPD were dense. However, the basophils, gonadotropes and thyrotropes were both, less active and reduced in size. Loss of cells at certain regions (PPD) and vacuolization was noticed (Fig. $1(7,8,9)$.

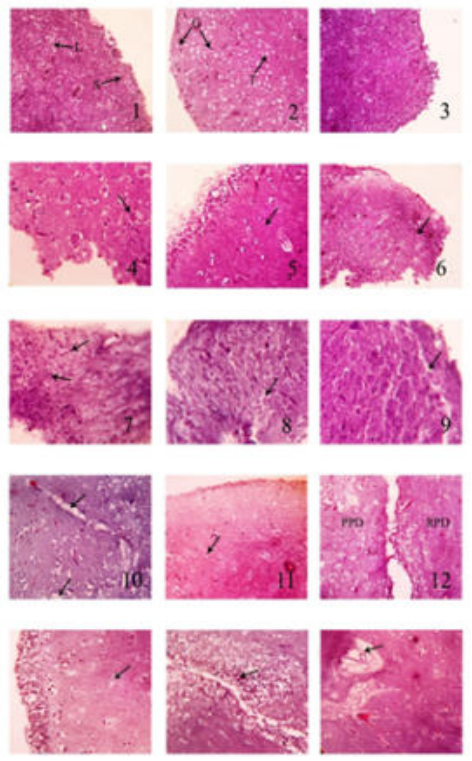

Figure 1: Microphotograph of pituitary gland of C. mrigala exposed to different concentrations of lead acetate (1-3: Section of pituitary gland of C. mrigala from control group (400X)., 4-6: Section of pituitary gland of C. mrigala exposed to LC0 concentration of lead acetate (400X). (Arrow in 5 indicates vacuolization and 6 shows vacuolization.). 7-9: Section of pituitary gland of C. mrigala exposed to LC50 concentration of lead acetate (400X). (Arrow in figures indicates vacuolization in cells and separation of cells.), 1012: Section of pituitary gland of C. mrigala exposed to 1/20th of LC50 concentration of lead acetate (400X). (Arrow in figure 10 indicates dilation in nerve fibers.), 13-15: Section of pituitary gland of C. mrigala exposed to 1/10th of LC50 concentration of lead acetate (400X). (Arrow in 13 indicates vacuolization, in 14 , it indicates alterations in compact arrangement of cells while in figure 15, it indicates appearance of cystic structure.) In figures, $\mathbf{G}-$ Gonadotropes.
M - Melanocyte, PI - Pars intermedia, T - Thyrotropes, S Somatotropes.

A-4) Chronic: Chronic effect of 1/20th (14.1ppm) of LC50 concentration of lead acetate for 30 days has shown disintegration in the glandular parts. The compact arrangement and dense population were altered and a scarce population of each type of cell was observed. Gonadotropes appeared to be rare. Loss of nuclei from different cells was common. Cytoplasmic degranulation in some of the cells was also noticed. Atrophy and weak reactivity with the dyes was observed.The RPD and PPD demarcating cleft was prominent. Disintegration of cells at certain regions was seen. Small cystic structures filled with a proteinaceous colloid like material were seen. Pituitary showed small cystic lesions in Rathke's cleft (Fig. $1(10,11,12))$.

The exposure at 1/10th (28.2 ppm) of LC50 concentration of lead acetate for 30 days showed intense effects as compared to exposure to $1 / 20$ th $(14.1 \mathrm{ppm})$ of LC50 concentration. Alterations in compact arrangement and dense population were extreme (Fig. 1 $(13,14,15)$ ). Number of all types of cells were decreased. Vacuolization, loss of structural integrity in PPD cells was observed. Presence of large intercellular spaces between cells of pituitary gland suggested that the cells are atrophic and the gland is structurally impaired. Small cystic structures filled with a proteinaceous colloid like material were seen in PPD. The cystic structures may be due to inflammation of gonadotropes. Pituitary also showed small cystic lesions in Rathke's cleft.

Immunohistochemistry of pituitary gland after exposure to heavy metals

A) Changes in pituitary gland after exposure to heavy metals The normal histological structure and changes induced by lead acetate in pituitary gland of C. mrigala at acute and chronic concentrations are shown by immunohistochemical means in Fig. 2.

B) A-1) Control Pituitary Gland: The control pituitary gland showed a spherical appearance.

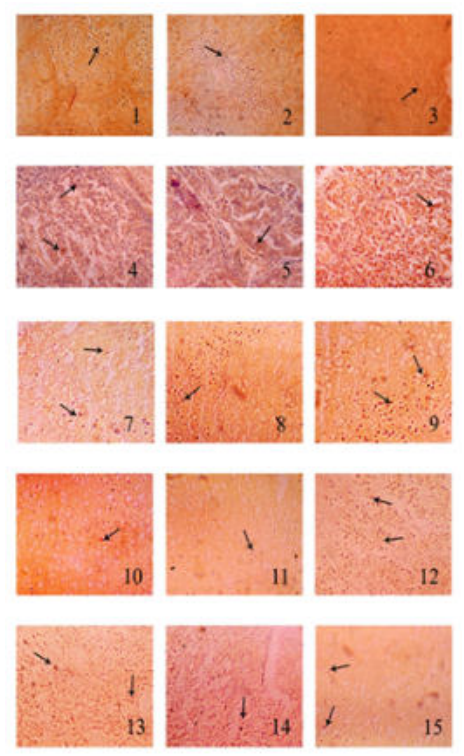

Figure 2: Microphotograph of pituitary gland of C. mrigala exposed to different concentrations of lead acetate (Demonstration by immunohistochemistry) 1-3: Section of pituitary gland of C. mrigala from control group (400X). 4-6: Section of pituitary gland of C. mrigala exposed to LC0 concentration of lead acetate (400X). 7-9: Section of pituitary gland of C. mrigala exposed to LC50 concentration of lead acetate (400X). 10-12: Section of pituitary gland of C. mrigala 
exposed to $1 / 20^{\text {th }}$ of LC50 concentration of lead acetate (400X). 13-15: Section of pituitary gland of C. mrigala exposed to $1 / 10^{\text {th }}$ of LC50 concentration of lead acetate (400X). (Arrow in all figures indicates immunoreactivity.)

Histologically the gland showed two distinguished components adenohypophysis and neurohypophysis. The typical three regions of adenohypophysis RPD, PPD and PI were recognizable. The RPD showed smaller but distinct acidophils. The PPD was populated by small gonadotropes. Thyrotropes and somatotropes were also observed. The gonadotropes were without secretary granules. The gonadotropes showed immunoreactivity with anti HCG. The reactivity was moderate (Fig. $2(1,2,3)$ ).

C) A-2) LC0: The examination of pituitary gland after exposure to LC0 concentration (250ppm) of lead acetate for $96 \mathrm{~h}$, showed similar organization of the cells like control. However, the population of all types of cells appeared to be decreased. The abundance of gonadotropes was reduced. The immunoreactivity (Fig. $2(4,5,6)$ ) was reduced as compared to control.

D) A-3) LC50: The examination of pituitary gland after exposure to LC50 concentration (282ppm) of lead acetate for $96 \mathrm{~h}$ showed altered organization. Acidophils in RPD and PPD were dense. However, the basophils, gonadotropes and thyrotropes were both less active and reduced in size. Immunoreactivity was reduced as compared to control. (Fig. 2 $(7,8,9)$

E) A-4) Chronic: Chronic effect of $1 / 20^{\text {th }}$ (14.1ppm) of LC50 concentration of lead acetate for 30 days has shown disintegration in the glandular parts. The compact arrangement and dense population of gonadotropes was altered and a scarce population was observed. Atrophy of gonadotropes was seen. Atrophy resulted in weak reactivity with the antibodies. There was a considerable reduction in immunoreactivity of gonadotropes (Fig. $2(10,11,12)$. Small cystic structures filled with a proteinaceous collide like material were seen. Pituitary showed small cystic lesions in Rathke's cleft. The exposure at $1 / 10^{\text {th }}(28.2 \mathrm{ppm})$ of LC50 concentration of lead acetate for 30 days showed intense effects as compared to exposure to $1 / 20^{\text {th }}(28.2 \mathrm{ppm})$ of LC50 concentration. Alterations in compact arrangement and dense population were extreme. Number of all types of cells decreased. Vacuolization, loss of structural integrity in PPD cells was observed. Presence of large intercellular spaces between cells of pituitary gland suggested that the cells are atrophic and the gland is structurally impaired. Small cystic structures filled with a proteinaceous colloid like material were seen in PPD. The cystic structures may be due to inflammation of gonadotropes. Pituitary also showed small cystic lesions in Rathke's cleft. The alterations produced due to lead acetate exposure resulted in reduced immunoreactivity in the pituitary gland (Fig. 2 (7-15)).

\section{DISCUSSION}

Absorption of lead through different organs in fish may lead to high mortality and cause many biochemical and histological alterations in survived fish [26]. The gonads of teleosts are affected by lead followed by alterations in reproductive behaviour [27]. Puntius conchnofus exposed to copper, zinc and lead resulted in disappearance of oocytes from the ovaries [28] by inducing atresia in ovary [29].

Detection of causes of fish mortality after exposure to lead need studies on central nervous system [30]. $\mathrm{Pb}$ contamination may alter endocrine regulated processes such as longevity, development, sexual receptivity, fertility and locomotion [31]. Gonads of teleosts are affected by lead pollution which thereby affect reproductive behaviour (Weber, 1993). Lead accumulation in brain of some fish species resulted in decreased reproductive potential due to alteration in hypothalamohypophyseal ovarian function [3233]. $\mathrm{Zn}, \mathrm{Pb}, \mathrm{Hg}$ and $\mathrm{As}$ interfere with sex hormones and adrenal cortex hormones steroidogenesis to alter reproduction and sex differentiation [31]. Effects of $\mathrm{Pb}$ on 17Bestradiol, testosterone and cortisol are biphasic, with stimulatory effects after low level exposure and inhibitory effects after high level exposure [34]. Heavy metals, such as arsenic, cadmium, copper, lead and mercury are known aquatic toxicants and cause deleterious effects on density, diversity and productivity of aquatic organisms [35]. Reproductive effects of heavy metals in combination have received little attention [36]. Various heavy metals are often present in the same polluted environment at the same time, studies of their interactive effects on gonadal activity would be more meaningful.

Exposure to cadmium chloride in catfish Clarias batrachus caused a significant increase in the ACTH cells, while thyrotropin and gonadotropin secreting cells showed inactivation and accumulation of secretory products [37]. Chromium induced impact on the pituitary ovarian axis has been demonstrated [38]. Deleterious effects of cadmium on the pituitary gland were reported by Pundir and Saxena (1992) [39]. It is reported by Kumari and Gopal (1991) [40] in Puntius sarana that high concentrations of $\mathrm{CdCl}_{2}$ influence the pituitary gonadotropes by bringing about gradual accumulation of secretory granules. Pituitary secretory activity is affected by metals [41]. This endocrine gland is particularly sensitive target to cadmium toxicity [42]. Pundir et al. [43] studied pituitary gland of fish Puntius ticto after chronic exposure to cadmium. Further, loss of structural organization and change in shape and size of pituitary gland was reported. Prominent vacuolization was displayed by PPD cells. Singh et al. [44] studied pituitary gland of Heterpneustes fossilis in response to cythion and hexedrin treatment. Observations were similar in agreement with Pundir. et al [43] studied the pituitary gland of rainbow trout Salmo gairdneri fingerlings in response to hypotonic environment and thiourea and reported cellular lysis and vacuolization. Remarkable changes in pituitary gland and inflammation of pituitary gland of Puntius ticto exposed to weedone were observed by Verma et al., [45]. Gradual accumulation of secretary granules in gonadotropes was reported in cyprinid fish Puntius sarana exposed to high concentration of cadmium chloride [56]. Ronis et al., [46] 99 showed alterations in pituitary activity due to metals. Cadmium showed a cytotoxic effect on the gland with an evident alteration in adenohypophyseal cells. Murrel and walking catfish exposed to $10-50 \mu \mathrm{g} / \mathrm{l}$ of methyl mercury, inorganic mercury or a mercurial fungicide and smaller, inactive and fewer gonadotropes were reported, in both species [47]. Atrophic changes of the pituitary corticotropes in cortisol impaired fish from sites contaminated with heavy metals were shown by Hontela et al., (1992) [48]. The reduced cell size, reduced cell area and presence of large intercellular spaces indicate the atrophy and structural impairment. Hontela, (1997) [49] observed structural and functional impairement of pituitary in fish exposed to craft mill effluent with smaller corticotropes and larger intercellular spaces in the exposed fish. Favorito (2010) [28] suggested a direct correlation between accumulation of cadmium in the brain and alteration of the normal occurance and distribution of the corticotropes, lactotropes and gonadotropes cells and their secretary activity. Hachfi and Saklym (2010) [50]. reported that cadmium could be the toxicant principally acting on hypothalamic pituitary axis. Simultaneous exposure to cadmium and lead lower the membrane fluidity in pituitary gland. It affects the membrane function and cause alterations in receptor binding and secretary mechanisms of pituitary hormones (Pillai et al., 2002) [51]. In general, a number of trace elements have been shown to have a negative effect on endocrine function in fish. Ruby et al. (2000) investigated the effects of lead exposure on sexually maturing female rainbow trout. Fish exposed to $10 \mu \mathrm{g} / \mathrm{L}$ of waterborne lead $(\mathrm{Pb}(\mathrm{NO})$ ) 
during the period of recrudescence had significantly lower GSIs and oocyte diameters than control fish on $12^{\text {th }}$ day. In addition, Ruby et al. (2000) assessed the effect of lead on the pituitary gland, the source of GTH. They found that the mean number of GTH producing granular pituitary basophils was lower in lead exposed females than in controls, suggesting the site of action of lead may be the pituitary. Thomas (1988) administered lead to Atlantic croaker in the $\operatorname{diet}(1.34 \mathrm{mg} / 70 \mathrm{~g}$ fish/day). After 30 days, the GSI in the croaker was only 32 percent of controls. The exposure to lead also resulted in lower circulation. Cadmium has been associated with elevated levels of $\mathrm{E} 2$ and enhanced gonadal growth in female Atlantic croaker (Micropogonias undulatus).

In the present study, the pituitary gland of C.mrigala after exposure to lead acetate showed decrease in abundance of cellular population and distinct vacuolization in PPD cells. Smaller, inactive and fewer gonadotropes were observed in pituitary gland of treated fish. The results indicated the gonadotropes were primary targets of $\mathrm{Pb}$ toxicity [59]. Hontela et al., (1992), Kumari, M., Gopal, N. H. (1991), Favorito (2010) [34] in which toxic effects of $\mathrm{Pb}$ on pituitary gland were investigated. Thus, it is possible that small, inactive and structurally altered gonadotropes are a toxic response to the stress induced by $\mathrm{Pb}$.

\section{CONCLUSIONS}

Results from the present study demonstrate that the gonadotropes of Cirrhinus mrigala were the primary targets of $\mathrm{Pb}$ toxicity. $\mathrm{Pb}$ toxicity could disturb the pituitary gonadal cycle by structural and functional alterations in gonadotropes. The alterations in histology of different regions were correlated with the intensity and time of exposure to the toxicant. The histopathological studies with Azan staining and immunohistochemistry revealed that the sub lethal concentrations of xenobiotics like lead causes deleterious effects on pituitary gland of C. mrigala. Undesirable changes in gonadotropes may further lead to changes in gonadotropin levels. The present studies strongly suggest that lead may exert endocrine disruptions impairing the gonadotropes necessary for reproduction.

\section{ACKNOWLEDGEMENT}

The present work was supported by UGC under FDP. The author wishes to express the appreciation towards UGC and Shivaji University for the support.

\section{REFERENCES:}

[1] Nriagu. J. (1983). Lead and Lead Poisoning in Antiquity. Academic Press. New York, USA.

[2] Heinberg, R. (2011). The End of Growth: Adapting to Our New Economic Reality. New Society. Heinberg, R. (2009). Blackout: Coal, Climate and the Last Energy Crisis (Gabriola Island, BC:New Society Publishers

[3] Berrahal A. A., Nehdi A., Hajjaji N., Gharbi N., and El-Fazaa, S., (2007). Antioxidant enzymes activities and bilirubin level in adult rat treated with lead Incidence of lead toxicity on the activity of antioxidant enzymes and plasma bilirubin level in adult rats, C.R.Biol.330:581-588

[4] Abdallah, G.M.,El-Sayed S.M.,Abo-Salem O.M., (2010).Effect of lead toxicity on coenzyme $Q$ levels in rat tissues. Food Chem. Toxicol. 48: 1753- 1756

[5] Park, S. K., Schwartz,J.,Weisskopf, M.,Sparrow D. andVokonas P.S., (2006).Low level lead exposure, metabolic syndrome and heart rate variability. The VA normative aging study. Environ. Health Perspect. 114:1718-1724

[6] Delistraty, D., and Stone, A. (2007). Dioxins, metals and fish toxicity in ash residue from space heaters burning used motor oil. Chemosphere, 68: 907914

[7] Amar, A. P. and Weiss, M. H. (2003). Pituitary anatomy and physiology. Neurosurg. Clin. N.Am. 13:11-23

[8] Lal, B. (1964). Morphological, histological and histochemical studies of the pituitary gland of Cirrhina mrigala (Hamilton). Proc. Indian Aca. Sci. 59: 297317

[9] Val-Sella, M. V. and Guiffrida, R. (1977). Morphology of the carp hypophysis. Anat.Anz., 142:403-409

[10] Evans, D. (1998). The physiology of Fishes. 2nd edn., CRC Press, Boca Raton Florida.

[11] Lamolet, B., Pulichino, A. M., Lamonerie, T., Gauthier, Y, Brue, T., Enjalbert, A. and Drouin, J. (2001). A Pituitary Cell-Restricted T Box Factor, Tpit, Activates POMC Transcription in Cooperation with Pitx Homeoproteins. Cell. 6:849-59

[12] Zhao, J., Taverne, M. A., Van, W. G., Bevers, M. M. and Van, H. R. (2002). Immunohistochemical localization of growth hormone (GH), GH receptor (GHR), insulin-like growth factor I (IGF-I) and type I IGF-I receptor, and gene expression of GH and GHR in rat pre-antral follicles. Zygote 10:85-94

[13] Hifny, A., Hassan, A. S., Kamel, G. and Abo-Elmagad, A. (1982). Cyclic morphological variations in the gonadotropic cells in pituitary gland of ewe. Z Mikrosk Anat Forsch. 96: 203-211

[14] Vongratchranon, U., Kirirat, P., Suwanjarat, J. and Boonyou, P. (2005). Alteration of gonadotrophs in the pituitary gland during the annual reproductive cycle of the adult female sand goby (Oxyeleotris marmoratus), Songklanakarin J. Sci.Technol., (Suppl.1):437-445

[15] Filippa, V., Penissi, A. and Mohamed, F. (2005). Seasonal variations of gonadotropins in the pars distalis male Viscacha pituitary. Effect of chronic melatonin treatment. Eur.J.Histochem. 49:29-30

[16] Boas, M., Feldt-Rasmussen, U., Skakkebaek, N. E. and Main, K. M. (2006). Environmental chemicals and thyroid function. Eur. J. Endocrinol. 154 (5) 599-611.

[17] Carr, J. A. and Patiño, R. (2011). The hypothalamus pituitary thyroid axis in teleosts and amphibians: endocrine disruption and its consequences to natural populations. Gen. Comp. Endocrinol. 170:299-312

[18] Georgescu, B., Georgescu, C, D $\square \mathbf{r} \square$ ban, S., Bouaru A, Pa $\square$ cal $\square$ u, S. Georgescu B.(2011). Heavy Metals Acting as Endocrine Disrupters. Scientific Papers: Animal Science and Biotechnologies, 44

[19] Weber, D. N. (1993). Exposure to sublethal levels of waterborne lead alters reproductive behavior patterns in fathead minnows (Pimephales promelas) Neurotoxicol. 4:347-358

[20] Ronis, M. J.J., Badger,T. M., Shema, S. J., Roberson, P. K., Templer, L. and Ringer, D. (1998). Endocrine mechanisms underlying the growth effects of developmental lead exposure in the rat. J. Toxicol. Environ. Health. 54: 101120

[21] Ruby, S. M., Hull, R. and Anderson, P. (2000). Sublethal lead affects pituitary function of rainbow trout during exogenous vitellogenesis. Arch. Environ. Contam.Toxicol.38:46-51

[22] Lavicoli, I., Fontana, L., Bergamaschi, A. (2009). The effects of metals as endocrine disruptors. Toxicol. Environ. Health B Crit. Rev. 12:206-223

[23] Ronis, M. J., Badger, T. M., Shema, S. J., Roberson, P. K. and Shaikh, F. (1996) Reproductive toxicity and growth effects in rats exposed to lead at different periods during development.Toxicol.Appl.Pharmacol. 136:361-371

[24] Finney D.J.(1971): Probit Analysis, 3rd Edition, Cambridge University Press

[25] Koneff, A. A. (1938). Adaptation of the Mallory azan staining method to the anterior pituitary of the rat. Stain Technol. 347

[26] Thomas, P. and Trant, J. M. (1989). Evidence that 17】, 20】, 21-trihydroxy-4pregnen3-one is a maturation-inducing steroid in spotted seatrout. Fish Physiol.Biochem. 7:185-191.

[27] Weber, D. N. (1993). Exposure to sublethal levels of waterborne lead alters reproductive behavior patterns in fathead minnows (Pimephales promelas) Neurotoxicol. 4:347-358

[28] Kumar, S. and Pant, S. C. (1984). Comparative effects of the sublethal poisoning of zinc copper and lead on the gonads of the teleost Puntius conchonius ham.J.Toxicol.Letters. 23: 189-194

[29] Mokhtar, D. M. and Abd-Elhafeez, H. H. (2013). Histological Changes in Selected Organs of Oreochromis niloticus Exposed to Doses of Lead Acetate. J.Life Sci.Biomed. 3:256-263

[30] Van Dyk,J.C.,Pieterse, G.M. and vanVuren,J.H.J. (2007). Histological changes in the liver of Oreochromis mossambicus (Cichlidae) after exposure to cadmium and zinc.J. Ecotox. Environ. Saf. 66:432-440

[31] Georgescu, B., Georgescu, C, D $\square \mathbf{r} \square$ ban, S., Bouaru A, Pa $\square$ cal $\square$ u, S., Georgescu B. (2011). Heavy Metals Acting as Endocrine Disrupters. Scientific Papers: Animal Science and Biotechnologies, 44

[32] Tulasi, S. J., Reddy, P. U. M. and Ramanrao, J. V. (1989). Effects of lead on the spawning potential of the fresh water Fish, Anabas testudineus. Bull. Environ. Contam. Toxicol. 43:858-863

[33] Ronis, M. J., Badger, T. M., Shema, S. J., Roberson, P. K., Templer, L., Ringer, D , and Thomas, P. K. (1998). Endocrine mechanisms underlying the growth effects of developmental lead exposure in the rat. J. Toxicol. Environ. Health. 54: 101-120

[34] Chaube, R., Mishra, S. and Rahil Singh, K. (2010). In vitro effects of lead nitrate on steroid profiles in the post-vitellogenic ovary of the catfish Heteropneustes fossilis, Toxicol in vitro, 24: 1899-1904.

[35] Moore, J. W. and Ramamoorthy, S. (1984). Heavy metals in natural waters applied monitoring and impact assessment. Spring Series on Environmental Management, Springer-Verald, NewYork

[36] Spehar, R. L., Leonard, E. N. and De Foe, D. L. (1978). Chronic effects of cadmium and zinc mixtures on flagfish (Jordanella floridae). Trans. Am. Fish. Soc. 107:354-360

[37] Jadhao, A. G., Paul, P. L., and Rao, P. D., (1994). Effect of cadmium chloride on the pituitary, thyroid and gonads in the catfish, Clarias batrachus (Linn.) Functional and developmental morphology 4 (1):39-44

[38] Mishra, A. K. and Mohanty, B. (2009b). Effect of hexavalent chromium exposure on the pituitary interrenal axis of a teleost. Channa punctatus (Bloch). Chemosphere 76:982-988

[39] Pundir, R. and Saxena, A. B. (1992). Chronic toxic exposure of Cd on the pituitary gland of fish Puntius ticto and pattern of recoupment. J.Environ. Biol. 13:69-74.

[40] Kumari, M., Gopal, N. H. (1991). Cadmium induced histomorphological changes in the testis and pituitary gonadotrophic hormone secreting cells of the cyprinid Puntius sarana. Ital.J.Zool.58 (1):71-76

[41] Ronis, M. J., Badger, T. M., Shema, S. J., Roberson, P. K. and Shaikh, F. (1998) Effects on pubertal growth and reproduction in rats exposed to lead perinatally or continuously throughout development. J. Toxicol. Environ. Health. 53:327-341

[42] Lafuente, A., Marquez, N., Pérez-Lorenzo, M., Pazo, D. and Esquifino, A. I. (2001). Cadmium effects on hypothalamic-pituitary-testicular axis in male rats. Exp. Biol.Med.226:605-611

[43] Pundir, R. and Saxena, A. B. (1990). Seasonal changes in the testes of fish Puntius ticto, and their relation to heavy metal toxicity. Bull. Environ. Contam. Toxicol. 45:288-293

[44] Singh, H. and Singh, T. P. (1980). Thyroid activity and TSH potency of the pituitary gland and blood serum in response to cythion and hexadrin treatment in the fresh water catfish. Heteropneustes fossilis (Bloch). Env. Res. 22: $184-189$

[45] Verma, D. K., Routray, P., Nanda, P. K. and Sarangi, N. (2009). Seasonal variation in semen characteristics and biochemical composition of seminal plasma of 
mrigal. Cirrhinus mrigala (Ham.). Asian Fisher. Sci. 22:429-443

[46] Ronis, M.J.J., Badger, T.M., Shema, S.J., Roberson, P. K., Templer, L. and Ringer,

D. (1998). Endocrine mechanisms underlying the growth effects of developmental lead exposure in the rat. J. Toxicol. Environ. Health. 54: 10120

[47] Favorito, R., Grimaldi, M. C., Coppola. M. and Ferrandino, I. (2010). Effects of acute cadmium exposure on the pituitary gland of P. sicula. Open Zool.J. 3:3036

[48] Hontela, A., Rasmussen, J. B., Audet, C., and Chevalier, G. (1992). Im-paired cortisol stress response in fish from environments polluted by PAHs, PCBs and mercury. Arch Environ Con-tam Toxicol.22:278-283

[49] Hontela, A. (1997). Endocrine and physiological responses of fish to xenobiotics: role of glucocortisoid hormones. RevTox-icol. 1: 1-46

[50] Hachfi, L. and Saklym, R. (2010). Effect of Cd transferred via food product on spermatogenesis in the rat. Andrologia. 42(1):62-64

[51] Pillai, A., Laxmi Priya, P.N. and Gupta, S. (2002). Effects of combined exposure to lead and cadmium on pituitary membrane of female rats. Arch. Toxicol. 76 : 671-675 